\title{
Adipocytes from the infrapatellar fat pad of $O A$ patients modulate CD4+ T cell cytokine production
}

\author{
Andreea loan-Facsinay, Joanneke C Kwekkeboom, Margreet Kloppenburg, Rene EM Toes \\ From 6th European Workshop on Immune-Mediated Inflammatory Diseases \\ Nice, France. 23-25 November 2011
}

\begin{abstract}
Aim
As shown in previous studies, the infrapatellar fat pad (IFP) of OA patients has an inflammatory phenotype and is infiltrated with immune cells, including CD4+ $\mathrm{T}$ cells. Because several studies have shown that the phenotype of $\mathrm{CD} 4+\mathrm{T}$ cells in adipose tissue is changing with the adiposity of the individual, we hypothesized that this effect could be due to the modulation of infiltrating $\mathrm{T}$ cells by the tissue-resident adipocytes. Therefore, we investigated whether adipocytes from IFP can modulate $\mathrm{CD} 4+\mathrm{T}$ cell cytokine production.
\end{abstract}

\section{Methods}

CD4+ T cells were purified from peripheral blood mononuclear cells isolated from healthy volunteers. The purity of the $\mathrm{CD} 4+\mathrm{T}$ cells isolated using magnetic beads coated with anti-human CD4 was above $95 \%$. Plate-bound antiCD3 and soluble anti-CD28 antibodies were used to activate T cells. Adipocytes were isolated from IFP of OA patients by collagenase digestion and were either cultured with purified CD4+ T cells or were cultured in vitro for 24 hours in DMEM/F12 medium supplemented with $0.5 \%$ bovine serum albumin to generate adipocyte-conditioned medium (ACM). Cytokine production was measured by intracellular cytokine staining (ICS), ELISA or cytokine multiplex. Separation of the protein and lipid fractions was performed using the Bligh and Dyer method, followed by precipitation of the protein fraction and reconstitution in culture medium.

\section{Results}

CD4+ T cells produced increase levels of IFN $\gamma$ when activated in the presence of adipocytes. This effect is mediated by soluble mediators, as shown in transwell and ACM

Dept. of Rheumatology, Leiden University Medical Center, Leiden, The Netherlands transfer experiments. Moreover, separation of the protein and lipid fractions from the ACM medium showed that soluble factors present in the protein fraction can mediate this effect. Measurement of ten different cytokines known to be secreted by $\mathrm{T}$ cells upon activation revealed that, besides IFN $\gamma$, also TNF $\alpha$, IL-17 and IL- 5 are modulated by IFP-derived ACM. Finally, CD4+ T cells from IFP produced more IFN $\gamma$ than blood CD4+ T cells from paired samples.

\section{Conclusions}

Soluble mediators secreted by IFP of OA patients can modulate cytokine production by $\mathrm{CD} 4+\mathrm{T}$ cells. These mediators are contained in the protein fraction in at least some patients.

Published: 23 November 2011

doi:10.1186/1479-5876-9-S2-P45

Cite this article as: Ioan-Facsinay et al:: Adipocytes from the infrapatellar fat pad of OA patients modulate CD4+ T cell cytokine production. Journal of Translational Medicine 2011 9(Suppl 2):P45.

Submit your next manuscript to BioMed Central and take full advantage of:

- Convenient online submission

- Thorough peer review

- No space constraints or color figure charges

- Immediate publication on acceptance

- Inclusion in PubMed, CAS, Scopus and Google Scholar

- Research which is freely available for redistribution

Submit your manuscript at www.biomedcentral.com/submit Biomed Central 